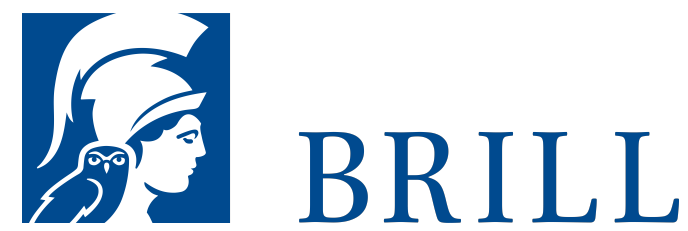

\title{
Human Rights and the Refugee Definition
}

\section{Comparative Legal Practice and Theory}

Editors: Bruce Burson and David James Cantor

Does human rights law help us to define who qualifies as a refugee? If so, then how? These deceptively simple questions sit at the heart of an intense contemporary debate over whether, or how, interpretation of the refugee definition in the Refugee Convention should take account of human rights law. In Human Rights and the Refugee Definition, Burson and Cantor bring a fine-grained comparative perspective to this debate. For the first time, they collect together in one edited volume over a dozen new studies by leading scholars and practitioners that explore in detail how these legal dynamics play out in a range of national and international jurisdictions and in relation to particular thematic challenges in refugee law.

\section{Readership}

All interested in refugee law and/or human rights law, including academics, post-graduate students, lawyers, judges and those working in refugee NGOs and international organisations.

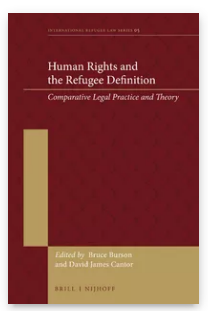

Pages: xvi, 412 pp.

Language: English

Subjects:

Refugee Law, Human Rights and

Humanitarian Law, Human

Rights, Human

Rights and

Humanitarian

Law,

International

Law: General

Interest,

International

Law, Public

International

Law,

International

Law

Publisher: Brill |

Nijhoff

Series:

International

Refugee Law

Series, Volume: 5

E-Book (PDF)

Released online: o2 Feb 2016

ISBN: 978-9004-28859-1 
Bruce Burson is a Senior Member of the New Zealand Immigration and Protection Tribunal and has issued many of its leading decisions in relation to the Refugee Convention.

David James Cantor, $\mathrm{PhD}$ (2010), is a Reader in International Human Rights Law and the Director of the Refugee Law Initiative at the School of Advanced Study, University of Hardback Publication date: 18 Feb 2016 ISBN: $978-90-$ 04-28858-4 List price USD $\mathrm{A}$ A 237.00

For more information see brill.com

Order information: Order online at brill.com +44330 3330049 | customerservices@brill.com Submission information: brill.com/authors

Titles published by Brill | Fink, Brill | mentis or Brill | Schöningh: +49(o)71 5413279216 | brill@brocom.de 